\title{
THE NEW PENOLOGY: NOTES ON THE EMERGING STRATEGY OF CORRECTIONS AND ITS IMPLICATIONS*
}

\author{
MALCOLM M. FEELEY \\ University of California at Berkeley \\ JONATHAN SIMON \\ University of Michigan
}

The new penology argues that an important new language of penology is emerging. This new language, which has its counterparts in other areas of the law as well, shifts focus away from the traditional concerns of the criminal law and criminology, which have focused on the individual, and redirects it to actuarial consideration of aggregates. This shift has a number of important implications: It facilitates development of a vision or model of a new type of criminal process that embraces increased reliance on imprisonment and that merges concerns for surveillance and custody, that shifts away from a concern with punishing individuals to managing aggregates of dangerous groups, and that affects the training and practice of criminologists.

It is often observed that penal ideology and practice became more conservative during the 1970s and 1980s (trends that may well continue in the 1990s). As important as this shift in the political valence of penal policy has been, it is only one part of a deeper change in conception-discourse, objectives, and techniques-in the penal process. These shifts have multiple and independent origins and are not reducible to any one reigning idea (e.g., getting tough on criminals). Despite their different origins, the elements of this emerging new conception have coalesced to form what may be thought of as a new strategic formation in the penal field, which we call (for lack of a more descriptive term) the new penology. 1

* An earlier version of this paper was originally presented at the California Conference on Growth and Its Impact on Correctional Policy, University of California at Berkeley, June 1992.

Support for this study was provided in part by the Daniel and Florence Guggenheim Criminal Justice Program at Berkeley and a grant from Berkeley's Committee on Research. We deeply appreciate this support. We also wish to thank Albert Alschuler, Piers Beirne, Alfred Blumstein, John Berecochea, Rosann Greenspan, Sheldon Messinger, and Franklin Zimring for helpful comments on an earlier draft of this paper. We also wish to thank Kiara Jordan for her extraordinary editorial assistance.

1. By strategy we do not mean a conscious and coherent agenda employed by a determinate set of penal agents or others. Just as structural elements in a building conjoin to create a pattern of force relations quite different from their individual properties, the loose 
The transformations we call the new penology involve shifts in three distinct areas:

1. The emergence of new discourses: In particular, the language of probability and risk increasingly replaces earlier discourses of clinical diagnosis and retributive judgment. ${ }^{2}$

2. The formation of new objectives for the system: The objectives we have in mind are not simply new to the system (some of them have old antecedents) but are in some sense newly "systemic." We are especially interested in the increasing primacy given to the efficient control of internal system processes in place of the traditional objectives of rehabilitation and crime control. Goals like reducing "recidivism" have always been internally shaped in important ways (Maltz, 1984), but in the contemporary setting the sense that any external social referent is intended at all is becoming attenuated.

3. The deployment of new techniques: These techniques target offenders as an aggregate in place of traditional techniques for individualizing or creating equity.

It is fun to trace patterns in the runic distribution of institutional changes (for the same reasons academics are such inveterate crossword puzzle fans). However, we also think that the new penology has served a significant function in locking together some of the external factors impinging on the criminal justice system and in determining the prevailing responses of the system.

No other fact seems as defining for the current moment as the massive increase in the level of incarceration undertaken over the past decade and a half, during which rates of reported crime have risen only modestly and victimization rates have declined. ${ }^{3}$ The conventional understanding of this rise links it to demographic changes, social changes (like increased drug use),

set of interconnected developments that we call the new penology increasingly shapes the way the power to punish is exercised. Foucault's (1978:94) notion that power is both "intentional and nonsubjective" (which often seems like an academic "koan") provides a useful methodological tool here. The point is not to deny that people have deliberate strategies but that the overall configuration created by multiple strategies is itself "strategic" without being deliberate in the same way (Foucault, 1982:225).

2. Some have argued that contemporary penality evidences a concern for behavior rather than intentions or mental states (Cohen, 1985; Wilkins, 1973). We extend this argument. Below, we show how increasingly the individual, even as locus of behavior, is less and less salient as the penal enterprise shifts away from a concern with reforming the individual to managing segments of the "population."

3. The incarceration rate (per 100,000 resident population of each sex) has gone from 102 in 1974 to 244 in 1988 (Bureau of Justice Statistics, 1989:582). 
improvement in the efficiency of law enforcement, and increases in the punitiveness of sentencing systems. ${ }^{4}$ More can be accomplished with models that allow for the contingent interaction of all these factors (Zimring and Hawkins, 1991:157). A shortfall of this approach, however, is that it in effect holds constant the nature of the penal enterprise while varying external pressures and internal policy shifts. Our analysis of the new penology emphasizes more holistic features of the current penal formation.

The new penology is found among criminal justice practitioners and the research community. 5 However, it certainly has not (yet) emerged as a hegemonic strategy for crime and crime policy. For instance, it contrasts in many respects with the "tough on crime" rhetoric in the political arena. Political themes do get translated into the administrative practice of agencies like corrections and police. The problem (for the administrator at least) is whether they translate into anything that can provide a viable handle on the agency's tasks. Even the seemingly coherent command of legislatures and governors to "lock 'em up" leaves much unsaid about how to do it with existing resource allocations. The new penology has helped fill that gap even as it competes with crime control and other options as a master narrative for the system.

\section{THE OLD PENOLOGY}

The outlines of the "old" penology become most visible when one considers what has been shared across the perceived lines of opposition in modern corrections and criminal law. Modern American law, whose concepts still form the core of law school education, concentrates on individuals; the individual is the unit of analysis. This concern is especially emphasized in the criminal process. Criminal law focuses on intention in order to assign guilt. Criminal procedure has erected barriers to conviction to test evidence and protect the accused individual in the face of the powerful state. Criminal sanctioning has been aimed at individual-based theories of punishment.

4. A critical analysis of claims based on all these factors can be found in Zimring and Hawkins (1991).

5. In this paper we do not deal at length with the methodological underpinnings of our approach. We should note, however, that it is informed by discussions that treat law as a communicative process, a system of discourse that, as it were, has a "life of its own." Thus, our objective is not to point to identifiable individuals who have articulated the positions or made the types of decisions we describe in this paper. Rather, we seek to identify the elements of the strategic formation that are becoming more salient-both consciously and unconsciously-to the operation of the penal process. This strategic field, as we shall argue, provides a new way of perceiving reality and as such becomes reality itself (Foucault, 1978; Garland, 1985; Habermas, 1974, 1985; Hay, 1975; Krygier, 1989; Nelkin, 1982; Teubner, 1989). 
In contrast, the new penology is markedly less concerned with responsibility, fault, moral sensibility, diagnosis, or intervention and treatment of the individual offender. Rather, it is concerned with techniques to identify, classify, and manage groupings sorted by dangerousness. The task is managerial, not transformative (Cohen, 1985; Garland and Young, 1983; Messinger, 1969; Messinger and Berecochea, 1990; Reichman, 1986; Wilkins, 1973). It seeks to regulate levels of deviance, not intervene or respond to individual deviants or social malformations.

Although the new penology is much more than "discourse," its language helps reveals this shift most strikingly. It does not speak of impaired individuals in need of treatment or of morally irresponsible persons who need to be held accountable for their actions. Rather, it considers the criminal justice system, and it pursues systemic rationality and efficiency. It seeks to sort and classify, to separate the less from the more dangerous, and to deploy control strategies rationally. The tools for this enterprise are "indicators," prediction tables, population projections, and the like. In these methods, individualized diagnosis and response is displaced by aggregate classification systems for purposes of surveillance, confinement, and control (Gordon, 1991).

\section{DISTINGUISHING FEATURES OF THE NEW PENOLOGY}

What we call the new penology is not a theory of crime or criminology. Its uniqueness lies less in conceptual integration than in a common focus on certain problems and a shared way of framing issues. This strategic formation of knowledge and power offers managers of the system a more or less coherent picture of the challenges they face and the kinds of solutions that are most likely to work. While we cannot reduce it to a set of principles, we can point to some of its most salient features.

\section{THE NEW DISCOURSE}

A central feature of the new discourse is the replacement of a moral or clinical description of the individual with an actuarial language of probabilistic calculations and statistical distributions applied to populations. Although social utility analysis or actuarial thinking is commonplace enough in modern life-it frames policy considerations of all sorts-in recent years this mode of thinking has gained ascendancy in legal discourse, a system of reasoning that traditionally has employed the language of morality and been focused on individuals (Simon, 1988). 6 For instance, this new mode of reasoning is found

6. A number of influential scholars have commented on this process, often calling attention to what they regard as the shortcomings of traditional individual-based legal language when applied to the problems of the modern organization-based society. See, e.g., dan-Cohen (1986), Stone (1975). 
increasingly in tort law, where traditional fault and negligence standardswhich require a focus on the individual and are based upon notions of individual responsibility-have given way to strict liability and no-fault. These new doctrines rest upon actuarial ways of thinking about how to "manage" accidents and public safety. They employ the language of social utility and management, not individual responsibility (Simon, 1987; Steiner, 1987).7 It is also found in some branches of antidiscrimination law, wherein the courts are less interested in intent (i.e., discrimination based on identifying individuals whose intentions can be examined) than in effects (i.e., aggregate consequences or patterns that can be assessed against a standard of social utility [Freeman, 1990] and corporate misconduct [dan-Cohen, 1986; Stone, 1975]). ${ }^{8}$

Although crime policy, criminal procedure, and criminal sanctioning have been influenced by such social utility analysis, there is no body of commentary on the criminal law that is equivalent to the body of social utility analysis for tort law doctrine. 9 Nor has strict liability in the criminal law achieved anything like the acceptance of related no-fault principles in tort law. Perhaps because the criminal law is so firmly rooted in a focus on the individual, these developments have come late to criminal law and penology.

Scholars of both European and North American penal strategies have noted the recent and rising trend of the penal system to target categories and subpopulations rather than individuals (Bottoms, 1983; Cohen, 1985; Mathieson, 1983; Reichman, 1986). This reflects, at least in part, the fact that actuarial forms of representation promote quantification as a way of visualizing populations.

Crime statistics have been a part of the discourse of the state for over 200 years, but the advance of statistical methods permits the formulation of concepts and strategies that allow direct relations between penal strategy and the population. Earlier generations used statistics to map the responses of normatively defined groups to punishment; today one talks of "high-rate offenders," "career criminals," and other categories defined by the distribution

7. In contrasting the "old" and the "new" tort law, Steiner (1987:8) observes: "They [judges with the new tort law] visualize the parties before them less as individual persons or discrete organizations and more as representatives of groups with identifiable common characteristics. They understand accidents and the social losses that accidents entail less as unique events and more as statistically predictable events. Modern social vision tends then toward the systemic-group-statistical in contrast with the vision more characteristic of the fault system, the dyadic-individual-unique."

8. There has been considerable resistance to the actuarial logic in this area as well. See McCleskey v. Kemp, 107 S. Ct. 1756 (1987).

9. But even here there are signs that this is changing. Although they do not frame their discussion in our terms, a number of scholars have observed that many of the provisions in the Racketeer Influenced and Corrupt Organizations (RICO) statute run counter to the traditional individual-based orientation of the criminal law and in fact are designed to facilitate regulation of organizational behavior, not individual conduct. 
itself. Rather than simply extending the capacity of the system to rehabilitate or control crime, actuarial classification has come increasingly to define the correctional enterprise itself.

The importance of actuarial language in the system will come as no surprise to anyone who has spent time observing it. Its significance, however, is often lost in the more spectacular shift in emphasis from rehabilitation to crime control. No doubt, a new and more punitive attitude toward the proper role of punishment has emerged in recent years, and it is manifest in a shift in the language of statutes, internal procedures, and academic scholarship. Yet looking across the past several decades, it appears that the pendulum-like swings of penal attitude moved independently of the actuarial language that has steadily crept into the discourse. 10

The discourse of the new penology is not simply one of greater quantification; it is also characterized by an emphasis on the systemic and on formal rationality. While the history of systems theory and operations research has yet to be written, their progression from business administration to the military and, in the 1960s, to domestic public policy must be counted as among the most significant of current intellectual trends. In criminal justice the great reports of the late 1960s, like The Challenge of Crime in a Free Society (see note 10), helped make the phrase "criminal justice system" a part of everyday reality for the operatives and students of criminal law and policy.11

Some of the most astute observers identified this change near the outset and understood that it was distinct from the concurrent rightward shift in penal thinking. Jacobs (1977) noted the rise at Stateville Penitentiary of what he called a "managerial" perspective during the mid-1970s. The regime of Warden Brierton was characterized, according to Jacobs, by a focus on tighter administrative control through the gathering and distribution of statistical information about the functioning of the prison. Throughout the 1980 s this perspective grew considerably within the correctional system. Jacobs presciently noted that the managerial perspective might succeed where traditional and reform administrations had failed because it was capable of handling the greatly increased demands for rationality and accountability coming from the courts and the political system.

10. A good example of this is the President's Commission on Law Enforcement and Administration of Justice, created in 1966. Its report, The Challenge of Crime in a Free Society (1967), combined a commitment to the rehabilitative ideal with a new enthusiasm for actuarial representation. Indeed, that document represents an important point of coalescence for many of the elements that make up the new penology.

11. Not everyone believes that this has been a positive change. For a critical perspective see Kelling (1991). 


\section{THE NEW OBJECTIVES}

The new penology is neither about punishing nor about rehabilitating individuals. It is about identifying and managing unruly groups. It is concerned with the rationality not of individual behavior or even community organization, but of managerial processes. Its goal is not to eliminate crime but to make it tolerable through systemic coordination.

One measure of the shift away from trying to normalize offenders and toward trying to manage them is seen in the declining significance of recidivism. Under the old penology, recidivism was a nearly universal criterion for assessing successor failure of penal programs. Under the new penology, recidivism rates continue to be important, but their significance has changed. The word itself seems to be used less often precisely because it carries a normative connotation that reintegrating offenders into the community is the major objective. High rates of parolees being returned to prison once indicated program failure; now they are offered as evidence of efficiency and effectiveness of parole as a control apparatus. 12

It is possible that recidivism is dropping out of the vocabulary as an adjustment to harsh realities and is a way of avoiding charges of institutional failure. Nearly half of all prisoners released in eleven of the largest states during 1983 were reconvicted within three years (Flanagan and Maguire, 1990). In 21 of the 48 states with adults on parole supervision in 1988, more than $30 \%$ of those leaving parole were in jail or prison on new criminal or parole-revocation charges (Bureau of Justice Statistics, 1989:100); in 8 of them more than half of those leaving parole were returned to confinement (including a spectacular $78 \%$ in California and $70 \%$ in Washington). ${ }^{13}$ However, in shifting to emphasize the virtues of return as an indication of effective control, the new penology reshapes one's understanding of the functions of the penal sanction. By emphasizing correctional programs in terms of aggregate control and system management rather than individual success and failure, the new penology lowers one's expectations about the criminal sanction. These redefined objectives are reinforced by the new discourses discussed above,

12. This is especially true for a number of new, intensive parole and probation supervision programs that have been established in recent years. Initially conceived as a way to reintegrate offenders into the community through a close interpersonal relationship between agent and offender, intensive supervision is now considered as an enhanced monitoring technique whose ability to detect high rates of technical violations indicates its success, not failure.

13. Probation, which involves huge numbers, many first offenders, and caseloads too huge even to apply techniques like drug testing to, does not send as high a proportion to incarceration. Still, nationwide, almost a fifth of all adults leaving state probation in 1988 either absconded or were incarcerated (Bureau of Justice Statistics, 1989:27). In California, $44 \%$ of adults leaving probation were incarcerated on the original charge for which they received probation (ibid.). 
which take deviance as a given, mute aspirations for individual reformation, and seek to classify, sort, and manage dangerous groups efficiently.

The waning of concern over recidivism reveals fundamental changes in the very penal processes that recidivism once was used to evaluate. For example, although parole and probation have long been justified as means of reintegrating offenders into the community (President's Commission, 1967:165), increasingly they are being perceived as cost-effective ways of imposing longterm management on the dangerous. Instead of treating revocation of parole and probation as a mechanism to short-circuit the supervision process when the risks to public safety become unacceptable, the system now treats revocation as a cost-effective way to police and sanction a chronically troublesome population. In such an operation, recidivism is either irrelevant ${ }^{14}$ or, as suggested above, is stood on its head and transformed into an indicator of success in a new form of law enforcement.

The importance that recidivism once had in evaluating the performance of corrections is now being taken up by measures of system functioning. Heydebrand and Seron (1990) have noted a tendency in courts and other social agencies toward decoupling performance evaluation from external social objectives. Instead of social norms like the elimination of crime, reintegration into the community, or public safety, institutions begin to measure their own outputs as indicators of performance. Thus, courts may look at docket flow. Similarly, parole agencies may shift evaluations of performance to, say, the time elapsed between arrests and due process hearings. In much the same way, many schools have come to focus on standardized test performance rather than on reading or mathematics, and some have begun to see teaching itself as the process of teaching students how to take such tests (Heydebrand and Seron, 1990:190-194; Lipsky, 1980:4-53).

Such technocratic rationalization tends to insulate institutions from the messy, hard-to-control demands of the social world. By limiting their exposure to indicators that they can control, managers ensure that their problems will have solutions. No doubt this tendency in the new penology is, in part, a response to the acceleration of demands for rationality and accountability in punishment coming from the courts and legislatures during the $1970 \mathrm{~s}$ (Jacobs, 1977). It also reflects the lowered expectations for the penal system that result from failures to accomplish more ambitious promises of the past. Yet in the end, the inclination of the system to measure its success against its own production processes helps lock the system into a mode of operation that

14. This does not mean that recidivism ceases to be a meaningful concept, but only that in its new mode of operation the penal system no longer accords it the centrality it once had. Recidivism remains a potent tool of criticism of the system, especially given its former significance. See, e.g., the California Legislative Analyst's Report to the 1989/1990 Budget (Sacramento), which contains a strong attack on the parole process for emphasizing the high rate of recidivism. 
has only an attenuated connection with the social purposes of punishment. In the long term it becomes more difficult to evaluate an institution critically if there are no references to substantive social ends.

The new objectives also inevitably permeate through the courts into thinking about rights. The new penology replaces consideration of fault with predictions of dangerousness and safety management and, in so doing, modifies traditional individual-oriented doctrines of criminal procedure. This shift is illustrated in U.S. v. Salerno, 15 which upheld the preventive detention provision in the Bail Reform Act of 1984. Writing the opinion for the Court, then Associate Supreme Court Justice William Rehnquist reasoned that preventive detention does not trigger the same level of protection as other penal detentions because it is intended to manage risks rather than punish. While the distinction may have seemed disingenuous to some, it acknowledges the shift in objectives we have emphasized and redefines rights accordingly. 16

\section{NEW TECHNIQUES}

These altered, lowered expectations manifest themselves in the development of more cost-effective forms of custody and control and in new technologies to identify and classify risk. Among them are low frills, no-service custodial centers; various forms of electronic monitoring systems that impose a form of custody without walls; and new statistical techniques for assessing risk and predicting dangerousness. These new forms of control are not anchored in aspirations to rehabilitate, reintegrate, retrain, provide employment, or the like. They are justified in more blunt terms: variable detention depending upon risk assessment. 17

15. 107 S. Ct. 2045, 2101-2 (1987).

16. There is a rapidly growing literature on the Supreme Court's shift away from individual rights in the area of criminal procedure. See, e.g., the Supreme Court's recent decision finding that forced medication for a mentally ill prisoner is subject to diminished procedural review because it is essentially a risk-management decision on the part of custodial managers rather than a punitive deprivation, Washington v. Harper, $110 \mathrm{~S}$. Ct. 1028, 1039-40 (1990). For a discussion of shifts in criminal procedure more generally, see Greenspan (1988).

17. In recent years one of the authors has spent time with corrections officials in Japan and Sweden as well as the United States and found that significantly different language is used to characterize penal policies. In Sweden he heard the language of therapy and rehabilitation (the offender is not properly socialized and requires rehabilitative therapy). In Japan he heard the language of moral repsonsibility (the offender is morally deficient and needs instruction in responsibility to the community). In the United States, he heard the language of management (in a high-crime society, we need expanded capacity to classify offenders in order to incapacitate the most dangerous and employ less stringent controls on the less dangerous). Juxtaposed against each other, the differences are dramatic.

There is a similarity in approach between the new penology and the views expressed by Soviet legal theorist Eugenii Pashukanis (1978). He predicted that under socialism, law 
Perhaps the clearest example of the new penology's method is the theory of incapacitation, which has become the predominant utilitarian model of punishment (Greenwood, 1982; Moore et al., 1984). Incapacitation promises to reduce the effects of crime in society not by altering either offender or social context, but by rearranging the distribution of offenders in society. If the prison can do nothing else, incapacitation theory holds, it can detain offenders for a time and thus delay their resumption of criminal activity. According to the theory, if such delays are sustained for enough time and for enough offenders, significant aggregate effects in crime can take place although individual destinies are only marginally altered. 18

These aggregate effects can be further intensified, in some accounts, by a strategy of selective incapacitation. This approach proposes a sentencing scheme in which lengths of sentence depend not upon the nature of the criminal offense or upon an assessment of the character of the offender, but upon risk profiles. Its objectives are to identify high-risk offenders and to maintain long-term control over them while investing in shorter terms and less intrusive control over lower risk offenders.

Selective incapacitation was first formally articulated as a coherent scheme for punishing in a report by a research and development organization (Greenwood, 1982), but it was quickly embraced and self-consciously promoted as a justification for punishment by a team of scholars from Harvard University, who were keenly aware that it constituted a paradigm shift in the underlying rationale for imposing the criminal sanction (Moore et al., 1984). ${ }^{19}$

\section{THE NEW PENOLOGY IN PERSPECTIVE}

The correctional practices emerging from the shifts we identified above

would "wither away" and be replaced with management based upon considerations of social utility rather than traditional individualized considerations. See, e.g., Sharlet (1978).

18. Incapacitation then is to penology what arbitrage is to investments, a method of capitalizing on minute displacements in time; and like arbitrage it has a diminished relationship to the normative goal of enhancing the value of its objects.

19. Throughout the book the authors acknowledge the significance of their approach. They warn, "When one holds these tests [use of correlates to serious criminal activity as a basis for formulating sentences] to a more exacting standard emphasizing individual justice, however, the proposed tests have greater difficulty; inaccuracy, resulting in false positives, and the inclusion of variables that are not entirely under the control of individuals and are not in themselves dangerous criminal conduct" (p. 76).

Throughout the book, they repeatedly express similar warnings, e.g., "A . . question is whether narrowing the focus of the system weakens the power and stature of the criminal law." (p. 90); "At the foundation of selective incapacitation is the distinctly illiberal view that people differ in their capacity for evil and that these differences are not the result of broad social processes but of something inherent in the individual" (p. 91). Ultimately, they conclude, "In our view the threshold objections to selective incapacitation do mark out important areas of vulnerability and uncertainty, but none stands as an absolute barrier to further consideration on the issue" (p. 92). 
present a kind of "custodial continuum." But unlike the "correctional continuum" discussed in the 1960 s, this new custodial continuum does not design penal measures for the particular needs of the individual or the community. Rather, it sorts individuals into groups according to the degree of control warranted by their risk profiles.

At one extreme the prison provides maximum security at a high cost for those who pose the greatest risks, and at the other probation provides lowcost surveillance for low-risk offenders. In between stretches a growing range of intermediate supervisory and surveillance techniques. The management concerns of the new penology-in contrast to the transformative concerns of the old-are displayed especially clearly in justifications for various new intermediate sanctions.

What we call the new penology is only beginning to take conherent shape. Although most of what we have stressed as its central elements-statistical prediction, concern with groups, strategies of management-have a long history in penology, in recent years they have come to the fore, and their functions have coalesced and expanded to form a new strategic approach. Discussing the new penology in terms of discourse, objective, and technique, risks a certain repetitiveness. Indeed, all three are closely linked, and while none can be assigned priority as the cause of the others, each entails and facilitates the others.

Thus, one can speak of normalizing individuals, but when the emphasis is on separating people into distinct and independent categories the idea of the "normal" itself becomes obscured if not irrelevant. 20 If the "norm" can no longer function as a relevant criterion of success for the organizations of criminal justice, it is not surprising that evaluation turns to indicators of internal system performance. The focus of the system on the efficiency of its own outputs, in turn, places a premium on those methods (e.g., risk screening, sorting, and monitoring) that fit wholly within the bureaucratic capacities of the apparatus.

But the same story can be told in a different order. The steady bureaucratization of the correctional apparatus during the 1950s and 1960s shifted the target from individuals, who did not fit easily into centralized administration, to categories or classes, which do. But once the focus is on categories of offenders rather than individuals, methods naturally shift toward mechanisms of appraising and arranging groups rather than intervening in the lives of individuals. In the end the search for causal order is at least premature.

In the section below we explore the contours of some of the new patterns represented by these developments, and in so doing suggest that the enterprise is by now relatively well established.

20. The mean of a multinomial variable is incoherent. 


\section{NEW FUNCTIONS AND TRADITIONAL FORMS}

Someday perhaps, the new penology will have its own Jeremy Bentham or Zebulon Brockway (Foucault, 1977:200; Rothman, 1980:33), some gigantic figure who can stamp his or her own sense of order on the messy results of incremental change. For now it is better not to think of it so much as a theory or program conceived in full by any particular actors in the system, but as an interpretive net that can help reveal in the present some of the directions the future may take. The test of such a net, to which we now turn, is not its elegance as a model but whether it enables one to grasp a wide set of developments in an enlightening way (in short, does it catch fish?). Below we reexamine three of the major features of the contemporary penal landscape in light of our argument-the expansion of the penal sanction, the rise of drug testing, and innovation within the criminal process-and relate them to our thesis.

\section{THE EXPANSION OF PENAL SANCTIONS}

During the past decade the number of people covered by penal sanctions has expanded significantly.21 Because of its high costs, the growth of prison populations has drawn the greatest attention, but probation and parole have increased at a proportionate or faster rate. The importance of these other sanctions goes beyond their ability to stretch penal resources; they expand and redistribute the use of imprisonment. Probation and parole violations now constitute a major source of prison inmates, and negotiations over probation revocation are replacing plea bargaining as modes of disposition (Greenspan, 1988; Messinger and Berecochea, 1990).22

Many probation and parole revocations are triggered by events, like failing a drug test, that are driven by parole procedures themselves (Simon, 1990; Zimring and Hawkins, 1991). The increased flow of probationers and parolees into prisons is expanding the prison population and changing the nature of the prison. Increasingly, prisons are short-term holding pens for violators deemed too dangerous to remain on the streets. To the extent the prison is organized to receive such people, its correctional mission is replaced by a management function, a warehouse for the highest risk classes of offenders.

From the perspective of the new penology, the growth of community corrections in the shadow of imprisonment is not surprising. ${ }^{23}$ The new penology does not regard prison as a special institution capable of making a

21. In 1988, 3.7 million adults were under some form of correctional sanction in the United States, a $38.8 \%$ increase since 1984 (Bureau of Justice Statistics, 1989:5).

22. In 1988 there were 14 states in which more than a quarter of all prison admissions came from parole revocation (Bureau of Justice Statistics, 1989:69). In California, in 1988, $59 \%$ of admissions were from parole revocations (ibid.).

23. The importance of supervisory sanctions is all the more interesting given the effort 
difference in the individuals who pass through it. Rather, it functions as but one of several custodial options. The actuarial logic of the new penology dictates an expansion of the continuum of control for more efficient risk management. For example, the various California prisons are today differentiated largely by the level of security they maintain and, thus, what level risk inmate they can receive. Twenty years ago, in contrast, they were differentiated by specialized functions: California Rehabilitation Center, for drug users; California Medical Prison at Vacaville, for the mentally ill; Deuel Vocational Institute, for young adults.

Thus, community-based sanctions can be understood in terms of risk management rather than rehabilitative or correctional aspirations. Rather than instruments of reintegrating offenders into the community, they function as mechanisms to maintain control, often through frequent drug testing, over low-risk offenders for whom the more secure forms of custody are judged too expensive or unnecessary. 24

The new penology's technique of aggregation has been incorporated in a number of sentencing reforms. Minnesota and, more recently, the U.S. Sentencing Commission have made population an explicit concern. The U.S. Sentencing Guidelines, which provide for "fixed" sentences as determined by a 238-cell grid, specifies that the presumptive sentence is a function of prior record and seriousness of offense, but as Alschuler (1991) has shown, although these guidelines have been defended as a step toward providing equal justice, in fact they are based upon "rough aggregations and statistical averages," which mask significant differences among offenders and offenses. The guidelines movement, he observes, marks "a changed attitude toward sentencing-one that looks to collections of cases and to social harm rather than to individual offenders and punishments they deserve ... [and rather than] the circumstances of their cases" (p. 951).

\section{DRUGS AND PUNISHMENT}

Drug use and its detection and control have become central concerns of the penal system. No one observing the system today can fail to be struck by the increasingly tough laws directed against users and traffickers, well-publicized data that suggest that a majority of arrestees are drug users, and the increasing proportion of drug offenders sent to prison. 25

of recent sentencing reform to remove discretion from corrections offices and establish juridical control through legislatures, judges, and prosecutors (Zimring and Hawkins, 1991).

24. The public remains interested in punishment for its own sake, and the expansion of parole and probation is tied in some degree to the ability of penal managers to convince the public that these supervisory sanctions can be punitive as well as managerial.

25. Incarceration for drug offenses grew at twice the rate of other offenses between 1976 and 1984 (Zimring and Hawkins, 1991:164). 
In one sense, of course, the emphasis on drugs marks a continuity with the past 30 years of correctional history. Drug treatment and drug testing were hallmarks of the rehabilitative model in the 1950s and 1960s. The recent upsurge of concern with drugs may be attributed to the hardening of social attitudes toward drug use (especially in marked contrast to the tolerant 1970s), ${ }^{26}$ the introduction of virulent new drug products, like crack cocaine, and the disintegrating social conditions of the urban poor.

Without dismissing the relevance of these continuities and explanations for change, it is important to note that there are distinctive changes in the role of drugs in the current system that reflect the logic of the new penology. In place of the traditional emphasis on treatment and eradication, today's practices track drug use as a kind of risk indicator. The widespread evidence of drug use in the offending population leads not to new theories of crime causation but to more efficient ways of identifying those at highest risk of offending. With drug use so prevalent that it is found in a majority of arrestees in some large cities (Flanagan and Maguire, 1990:459), it can hardly mark a special type of individual deviance. From the perspective of the new penology, drug use is not so much a measure of individual acts of deviance as it is a mechanism for classifying the offender within a risk group.

Thus, one finds in the correctional system today a much greater emphasis on drug testing than on drug treatment. This may reflect the normal kinds of gaps in policy as well as difficulty in treating relatively new forms of drug abuse. Yet, testing serves functions in the new penology even in the absence of a treatment option. By marking the distribution of risk within the offender population under surveillance, testing makes possible greater coordination of scarce penal resources.

Testing also fills the gap left by the decline of traditional intervention strategies. One of the authors spent a year observing parole supervision in California, where drug testing was the predominant activity for agents (Simon, 1990). If nothing else, testing provided parole (and probably probation) agents a means to document compliance with their own internal performance requirements. Agents are supposed to meet with their parolees twice a month on average, but with few parolees working, they can often be hard to find. When they are located, there is often little to do or talk about since the agent cannot offer them a job or coerce them to take one. 27 Testing provides both an occasion for requiring the parolee to show up in the parole office and a purpose for meeting. The results of tests have become a network of fact and

26. Support for the legalization of marijuana, e.g., peaked among first year college students in 1977 at $52.9 \%$ and has since declined, reaching $16.7 \%$ in 1989 (Flanagan and Maguire, 1990:195).

27. The law no longer requires that parolees be employed, and jobs are not available in the communities where many parolees reside. 
explanation for use in a decision-making process that requires accountability but provides little substantive basis for distinguishing among offenders.

\section{INNOVATION}

Our description may seem to imply the onset of a reactive age in which penal managers strive to manage populations of marginal citizens with no concomitant effort toward integration into mainstream society. This may seem hard to square with the myriad new and innovative technologies introduced over the past decade. Indeed the media, which for years have portrayed the correctional system as a failure, have recently enthusiastically reported on these innovations: boot camps, electronic surveillance, high security "campuses" for drug users, house arrest, intensive parole and probation, and drug treatment programs.

Although some of the new proposals are presented in terms of the "old penology" and emphasize individuals, normalization, and rehabilitation, it is risky to come to any firm conviction about how these innovations will turn out. If historians of punishment have provided any clear lessons, it is that reforms evolve in ways quite different from the aims of their proponents (Foucault, 1977; Rothman, 1971). Thus, we wonder if these most recent innovations won't be recast in the terms outlined in this paper. Many of these innovations are compatible with the imperatives of the new penology, that is, managing a permanently dangerous population while maintaining the system at a minimum cost.

One of the current innovations most in vogue with the press and politicians are correctional "boot camps." These are minmum security custodial facilities, usually for youthful first offenders, designed on the model of a training center for military personnel, complete with barracks, physical exercise, and tough drill sergeants. Boot camps are portrayed as providing discipline and pride to young offenders brought up in the unrestrained culture of poverty (as though physical fitness could fill the gap left by the weakening of families, schools, neighborhoods, and other social organizations in the inner city).

The camps borrow explicity from a military model of discipline, which has influenced penality from at least the eighteenth century. 28 No doubt the image of inmates smartly dressed in uniforms performing drills and calisthenics appeals to long-standing ideals of order in post-Enlightenment culture. But in its proposed application to corrections, the military model is even less appropriate now than when it was rejected in the nineteenth century; indeed, today's boot camps are more a simulation of discipline than the real thing.

In the nineteenth century the military model was superseded by another

28. The prison borrowed from the earlier innovations in the organization of spaces and bodies undertaken by the most advanced European military forces. See, e.g., Rothman (1971:105-108). 
model of discipline, the factory. Inmates were controlled by making them work at hard industrial labor (Ignatieff, 1978; Rothman, 1971). It was assumed that forced labor would inculcate in offenders the discipline required of factory laborers, so that they might earn their keep while in custody and join the ranks of the usefully employed when released. One can argue that this model did not work very well, but at least it was coherent. The model of discipline through labor suited our capitalist democracy in a way the model of a militarized citizenry did not. 29

The recent decline of employment opportunities among the populations of urban poor most at risk for conventional crime involvement has left the applicability of industrial discipline in doubt. But the substitution of the boot camp for vocational training is even less plausible. Even if the typical 90-day regime of training envisioned by proponents of boot camps is effective in reorienting its subjects, at best it can only produce soldiers without a company to join. Indeed, the grim vision of the effect of boot camp is that it will be effective for those who will subsequently put their lessons of discipline and organization to use in street gangs and drug distribution networks. However, despite the earnestness with which the boot camp metaphor is touted, we suspect that the camps will be little more than holding pens for managing a short-term, mid-range risk population.

Drug testing and electronic monitors being tried in experimental "intensive supervision" and "house arrest" programs are justified in rehabilitative terms, but both sorts of programs lack a foundation in today's social and economic realities. The drug treatment programs in the 1960s encompassed a regime of coercive treatment: "inpatient" custody in secured settings followed by community supervision and reintegration (President's Commission, 1967). The record suggests that these programs had enduring effects for at least some of those who participated in them (Anglin et al., 1990). Today's proposals are similar, but it remains to be seen whether they can be effective in the absence of long-term treatment facilities, community-based follow-up, and prospects for viable conventional life-styles and employment opportunities. 30 In the

29. The model of industrial discipline was rarely fully achieved in prisons, but at least it had a clear referent in the real world, one that provided a certain coherence and plausibility to the penal project. The boot camp, like so much else in our increasingly anachronistic culture, is a signifier without a signified.

30. In his important 1966 essay "Work and Identity in the Lower Class," Rainwater suggested that members of the lower class often choose "expressive" life-styles of deviance in the absence of opportunities for the most prestigious and desirable roles in the occupational structure. But he argued they also predictably burn out and accept the identification offered by even low-level employment of the good worker and provider. Rainwater urged that keeping entry-level employment available and tolerable was essential to fostering that transition. Today, when entry-level employment has shrunk to levels not imagined in the mid-1960s, the transition of those who are dissuaded or simply burn out on crime cannot be assumed (Duster, 1987). 
meantime it is obvious that they can also serve the imperative of reducing the costs of correctional jurisdiction while maintaining some check on the offender population.

Our point is not to belittle the stated aspirations of current proposals or to argue that drug treatment programs cannot work. Indeed, we anticipate that drug treatment and rehabilitation will become increasingly attractive as the cost of long-term custody increases. However, given the emergence of the management concerns of the new penology, we question whether these innovations will embrace the long-term perspective of earlier successful treatment programs, and we suspect that they will emerge as control processes for managing and recycling selected risk populations. If so, these new programs will extend still further the capacity of the new penology. The undeniable attractiveness of boot camps, house arrest, secure drug "centers," and the like, is that they promise to provide secure custody in a more flexible format and at less cost than traditional correctional facilities. Indeed, some of them are envisioned as private contract facilities that can be expanded or reduced with relative ease. Further, they hold out the promise of expanding the range of low- and mid-level custodial alternatives, thereby facilitating the transfer of offenders now held in more expensive, higher security facilities that have been so favored in recent years. Tougher eligibility requirements, including job offers, stable residency, and promises of sponsorship in the community can be used to screen out "higher risk" categories for noncustodial release programs (Petersilia, 1987). Thus, despite the lingering language of rehabilitation and reintegration, the programs generated under the new penology can best be understood in terms of managing costs and controlling dangerous populations rather than social or personal transformation.

\section{SOCIAL BASES OF THE NEW PENOLOGY}

The point of these reinterpretations is not to show that shifts in the way the penal enterprise is understood and discussed inexorably determine how the system will take shape. What actually emerges in corrections over the near and distant future will depend on how this understanding itself is shaped by the pressures of demographic, economic, and political factors. Still, such factors rarely operate as pure forces. They are filtered through and expressed in terms in which the problems are understood. Thus, the strategic field we call the new penology itself will help shape the future.

\section{THE NEW DISCOURSE OF CRIME}

Like the old penology, traditional "sociological" criminology has focused on the relationship between individuals and communities. Its central concerns have been the causes and correlates of delinquent and criminal behavior, and it has sought to develop intervention strategies designed to correct 
delinquents and decrease the likelihood of deviant behavior. Thus, it has focused on the family and the workplace as important influences of socialization and control.

The new penology has an affinity with a new "actuarial" criminology, which eschews these traditional concerns of criminology. Instead of training in sociology or social work, increasingly the new criminologists are trained in operations research and systems analysis. This new approach is not a criminology at all, but an applied branch of systems theory. This shift in training and orientation has been accompanied by a shift in interest. A concern with successful intervention strategies, the province of the former, is replaced by models designed to optimize public safety through the management of aggregates, which is the province of the latter.

In one important sense this new criminology is simply a consequence of steady improvements in the quantitative rigor with which crime is studied. No doubt the amassing of a statistical picture of crime and the criminal justice system has improved researchers' ability to speak realistically about the distribution of crimes and the fairness of procedures. But, we submit, it has also contributed to a shift, a reconceptualization, in the way crime is understood as a social problem. ${ }^{31}$ The new techniques and the new language have facilitated reconceptualization of the way issues are framed and policies pursued. Sociological criminology tended to emphasize crime as a relationship between the individual and the normative expectations of his or her community (Bennett, 1981). ${ }^{32}$ Policies premised on this perspective addressed problems of reintegration, including the mismatch among individual motivation, normative orientation, and social opportunity structures. In contrast, actuarial criminology highlights the interaction of criminal justice institutions and specific segments of the population. Policy discussions framed in its terms emphasize the management of high-risk groups and make less salient the qualities of individual delinquents and their communities.

Indeed, even the use of predictive statistics by pioneers like Ernest Burgess (1936) reflected sociological criminology's emphasis on normalization. Burgess's statistics (and those of most other quantitative criminologists before the 1960s) measured the activity of subjects defined by a specifiable set of individual or social factors (e.g., alcoholism, unemployment, etc.). In the actuarial criminology of today, by contrast, the numbers generate the subject itself (e.g., the high-rate offender of incapacitation research). In short, criminals are no longer the organizing referent (or logos) of criminology. Instead,

31. Again, we would point to the 1967 President's Commission report as a critical point of emergence for the actuarial criminology that dominates today, especially the Task Force report on "Science and Technology" (Ch. 11).

32. The research relied on ethnography and life histories. See, e.g., the work of Blumstein et al. (1986), Burgess (1974), Shaw (1931), Sutherland (1934). 
criminology has become a subfield of a generalized public policy analysis discourse. This new criminal knowledge aims at rationalizing the operation of the systems that manage criminals, not dealing with criminality. The same techniques that can be used to improve the circulation of baggage in airports or delivery of food to troops can be used to improve the penal system's efficiency.

\section{THE DISCOURSE OF POVERTY AND THE "UNDERCLASS"}

The new penology may also be seen as responsive to the emergence of a new understanding of poverty in America. ${ }^{33}$ The term underclass is used today to characterize a segment of society that is viewed as permanently excluded from social mobility and economic integration. The term is used to refer to a largely black and Hispanic population living in concentrated zones of poverty in central cities, separated physically and institutionally from the suburban locus of mainstream social and economic life in America.

In contrast to groups whose members are deemed employable, even if they may be temporarily out of work, the underclass is understood as a permanently marginal population, without literacy, without skills, and without hope; a self-perpetuating and pathological segment of society that is not integratable into the larger whole, even as a reserve labor pool (Wilson, 1987). Conceived of this way, the underclass is also a dangerous class, not only for what any particular member may or may not do, but more generally for collective potential misbehavior. ${ }^{34}$ It is treated as a high-risk group that must be managed for the protection of the rest of society. Indeed, it is this managerial task that provides one of the most powerful sources for the imperative of

33. Although in this paper we emphasize recent significant shifts, a management approach is not wholly unprecedented. For instance, during the formative years of the development of the modern criminal justice system, the late eighteenth and the early nineteenth century, the term "dangerous classes" was used widely in discussions of English criminal justice policies. Influenced in part by Malthusian thinking and burgeoning urban populations, policy analysts of the time often treated criminal justice policy in aggregate management terms, treating crime as an indicator of the dangerousness of a larger group, rather than of individuals. For instance, transportation of convicted felons was often regarded as but one of several interrelated policies to export the dangerous classes. Other policies accomplishing similar ends were voluntary emigration and indentured servitude, both of which were actively promoted by the government. The invention of the large-scale prison helped to individualize crime policy.

34. A recent study estimated that on any one day in 1988 roughly one in every four young (between ages 20 and 29) black males was under some form of correctional custody (Mauer, 1990). More recently, a similar study calculated that on a given day in 1990 some $42 \%$ of all young black males in Washington, D.C., were in custody. The growing visibility of the link between penality and race is likely to reinforce the sense that crime is the product of a pathological subpopulation that cannot be integrated into the society at large, as well as the perception that the penal system can do no better than maintain custody over a large segment of this population. 
preventive management in the new penology. The concept of "underclass" makes clear why correctional officials increasingly regard as a bad joke the claim that their goal is to reintegrate offenders back into their communities.

Reintegration and rehabilitation inevitably imply a norm against which deviant subjects are evaluated. As Allen (1981) perceived more than a decade ago, rehabilitation as a project can only survive if public confidence in the viability and appropriateness of such norms endures. Allen viewed the decline of the rehabilitative ideal as a result of the cultural revolts of the 1960s, which undermined the capacity of the American middle classes to justify their norms and the imposition of those norms on others. It is this decline in social will, rather than empirical evidence of the failure of penal programs to rehabilitate, that, in Allen's analysis, doomed the rehabilitative ideal.

Whatever significance cultural radicalism may have had in initiating the breakup of the old penology in the mid-1970s, the emergence of the new penology in the 1980s reflects the influence of a more despairing view of poverty and the prospects for achieving equality (views that can hardly be blamed on the Left). Rehabilitating offenders, or any kind of reintegration strategy, can only make sense if the larger community from which offenders come is viewed as sharing a common normative universe with the communities of the middle classes-especially those values and expectations derived from the labor market. The concept of an underclass, with its connotation of a permanent marginality for whole portions of the population, has rendered the old penology incoherent and laid the groundwork for a strategic field that emphasizes low-cost management of a permanent offender population.

The connection between the new penality and the (re)emergent term underclass also is illustrated by recent studies of American jails. For instance, Irwin's 1985 book, The Jail, is subtitled Managing the Underclass in American Society. His thesis is that "prisoners in jails share two essential characteristics: detachment and disrepute" (p. 2). For Irwin, the function of jail is to manage the underclass, which he reports is also referred to as "rabble," "disorganized," "disorderly," and the "lowest class of people."

In one rough version of Irwin's analysis, the jail can be viewed as a means of controlling the most disruptive and unsightly members of the underclass. But in another version, it can be conceived of as an emergency service net for those who are in the most desperate straits. As other social services have shrunk, increasingly this task falls on the jail.

Whichever version one selects, few of those familiar with the jails in America's urban centers find it meaningful to characterize them only as facilities for "pretrial detention" or for serving "short-term sentences." Although not literally false, this characterization misses the broader function of the jail. The high rates of those released without charges filed, the turnstile-like frequency with which some people reappear, and the pathological characteristics 
of a high proportion of the inmates lead many to agree with Irwin that the jail is best understood as a social management instrument rather than an institution for effecting the purported aims of the criminal process.

Social management, not individualized justice, is also emphasized in other discussions of the criminal process. Long-time public defender, James $\mathbf{M}$. Doyle (1992), offers the metaphors "colonial," "White Man's burden," and "Third World," in an essay drawing parallels between the careers of criminal justice officials and colonial administrators. Both, he argues,

are convinced that they are menaced by both inscrutable, malign natives and ignorant, distant, policy-makers. They believe they are hamstrung by crazy legalities. Young Assistant District Attorneys, like young Assistant District Commissioners, hurriedly seize, then vehemently defend, a conventional wisdom as a protection against these threats. They pledge themselves to a professional code that sees the world in which people are divided into various collectives. Where they might have seen individuals, they see races, types, and colors instead. Like the colonialists before them, they embrace a "rigidly binomial opposition of 'ours' and 'theirs." "In the criminal justice system as on the frontiers of empire "the impersonal communal idea of being a White Man" rules; it becomes "a very concrete way of being-in-the-world, a way of taking hold of reality, language and thought" (p. 74).

Sustaining his metaphor, Doyle parallels the corrupting influence of the White Man's effort to "manage" third-world natives with those of the criminal justice professionals' effort to handle cases. He concludes, "we have paid too much attention to the superficial exotic charms by which the reports of the colonial and criminal justice White Man entertain us, too little to the darker strains they also share" (p. 126).

Whether one prefers Irwin's notion of underclass or Doyle's "colonial" and "third world" metaphors, both resonate with our notion of the new penology. They vividly explain who is being managed and why. But in providing an explanation of these relationships, there is a danger that the terms will reify the problem, that they will suggest the problem is inevitable and permanent. Indeed, it is this belief, we maintain, that has contributed to the lowered expectations of the new penology-away from an aspiration to affect individual lives through rehabilitative and transformative efforts and toward the more "realistic" task of monitoring and managing intractable groups.

The hardening of poverty in contemporary America reinforces this view. When combined with a pessimistic analysis implied by the term underclass, the structural barriers that maintain the large islands of third world misery in America's major cities can lead to the conclusion that such conditions are inevitable and impervious to social policy intervention. This, in turn, can push corrections ever further toward a self-understanding based on the 
imperative of herding a specific population that cannot be disaggregated and transformed but only maintained 35 - a kind of waste management function. ${ }^{36}$ As the recent events in Los Angeles demonstrate, however, this kind of reversion is likely to be fatal to a democratic civil order.

\section{CONCLUSION}

Our discussion has proceeded as if the new penology - the new way of conceiving of the functions of the criminal sanction-has contributed to the recent rise in prison populations. Although we believe that it has, we also acknowledge that the new penology is both cause and effect of the increases. We recognize that those conditions we referred to at the outset as "external" have placed pressures on criminal justice institutions that, in turn, have caused them to adapt in a host of ways. The point of our paper, however, has been to show just how thorough this adaptation has been. It has led to a significant reconceptualization of penology, a shift that institutionalizes those adaptive behaviors. It embraces the new forms that have arisen as a result of this adaptation. As such, the new language, the new conceptualization, ensures that these new forms will persist independently of the pressures. They appear to be permanent features of the criminal justice system.

\section{REFERENCES}

Allen, Francis

1981 The Decline of the Rehabilitative Idea. New Haven: Yale University Press.

Alschuler, Albert

1991 The failure of sentencing guidelines: A plea for less aggregation. University of Chicago Law Review 58:901-951.

Anglin, Douglas, George Speckhart, Elizabeth Piper Deschenes

1990 Examining the Effects of Narcotics Addiction. Los Angeles: UCLA Neuropsychiatric Institute, Drug Abuse Research Group.

Bennett, James

1981 Oral History and Delinquency: The Rhetoric of Criminology. Chicago: University of Chicago Press.

Blumstein, Alfred, Jacqueline Cohen, Jeffrey A. Roth, and Christy A. Visher (eds.)

1986 Criminal Careers and "Career Criminals." Washington, D.C.: National Academy Press.

35. However, those who work in corrections, whether they want to do social work or enforce laws, resist such deterministic ideas and resist conceiving of their jobs as recycling human beings from one level of custodial management to another with little reference to justice or social reintegration.

36. This term is more than metaphor. In 1989, then Governor Deukmejian of California proposed that prison inmates be used to process toxic wastes. 
Bottoms, Anthony

1983 Neglected features of contemporary penal systems. In David Garland and Peter Young (eds.), The Power to Punish. London: Heinemann.

Bureau of Justice Statistics

1989 Correctional Populations in the United States, 1988. Washington, D.C.:

U.S. Department of Justice.

Burgess, Ernest W.

1936 Protecting the public by parole and parole prediction. Journal of Criminal Law and Criminology 27:491-502.

1974 The Basic Writings of Ernest W. Burgess, ed. Donald Bogue. Chicago: University of Chicago Press.

Cohen, Stanley

1985 Visions of Social Control: Crime, Punishment and Classification. Oxford: Polity Press.

dan-Cohen, Meir

1986 Persons, Rights and Organizations. Berkeley: University of California Press.

Doyle, James M.

1992 "It's the Third World down there!": The colonialist vocation and American criminal justice. Harvard Civil Rights-Civil Liberties Law Review 27:71126.

Duster, Troy

1987 Crime, youth unemployment and the black urban underclass. Crime and Delinquency 33:300-316.

Foucault, Michel

1977 Discipline and Punishment. New York: Pantheon.

1978 The History of Sexuality. Vol. I, An Introduction. New York: Random House.

1982 The subject and power. In Hubert L. Dreyfus and Paul Rabinow (eds.), Michel Foucault: Beyond Structuralism and Hermenuetics. Chicago: University of Chicago Press.

Freeman, Alan

1990 Antidiscrimination law: The view from 1989. In David Kaiyrs (ed.), The Politics of Law. New York: Pantheon.

Garland, David

1985 Punishment and Welfare. Aldershot: Gower.

Garland, David and Peter Young (eds.)

1983 The Power to Punish: Contemporary Penality and Social Analysis. London: Heinemann.

Gordon, Diana R.

1991 The Justice Juggernaut: Fighting Street Crime, Controlling Citizens. New Brunswick: Rutgers University Press.

\section{Greenspan, Rosanne}

1988 The transformation of criminal due process in the administrative state. Paper prepared for delivery at the annual meeting of the Law and Society Association, Vail, Colo., June 1988. 
Greenwood, Peter

1982 Selective Incapacitation. Santa Monica, Calif.: Rand.

Habermas, Jurgen

1974 Communication and the Evolution of Society. Boston: Beacon Press.

1985 Law as medium and law as institution. In Gunther Teubner (ed.), Dilemmas of Law in the Welfare State. Berlin: de Gruyter.

Hay, Douglas

1975 Property, authority and the criminal law. In Douglas Hay, Peter Linebaugh, and Edward P. Thompson (eds.), Albion's Fatal Tree. New York: Pantheon.

Heydebrand, Wolf and Carroll Seron

1990 Rationalizing Justice: The Political Economy and Federal District Courts. New York: State University of New York Press.

Ignatieff, Michael

1978 A Just Measure of Pain: The Penitentiary in the Industrial Revolution, 1750-1850. London: Macmillan.

Irwin, John

1985 The Jail: Managing the Underclass in American Society. Berkeley: University of California Press.

Jacobs, James B.

1977 Stateville: The Penitentiary in Mass Society. Chicago: University of Chicago Press.

Kelling, George L.

1991 Crime and metaphor: Toward a new concept of policing. NY: The City Journal, Autumn:65-71.

Krygier, Martin

1989 Law as tradition. Law and Philosophy 5:237-262.

Lipsky, Michael

1980 Street Level Bureaucrats. New York: Russell Sage Foundation.

Maguire, Kathleen and Timothy J. Flanagan

1990 Sourcebook of Criminal Justice Statistics 1989. U.S. Department of Justice, Bureau of Justice Statistics, Washington, D.C.: U.S. Government Printing Office.

Maltz, Michael

1984 Recidivism. Orlando, Fla.: Academic Press.

Mathieson, Thomas

1983 The future of control systems-The case of Norway. In David Garland and Peter Young (eds.), The Power to Punish. London: Heinemann.

Mauer, Marc

1990 Young black men and the criminal justice system. Washington, D.C.: The Sentencing Project.

Messinger, Sheldon

1969 Strategies of control. Ph.D. dissertation, Department of Sociology, University of California at Los Angeles. 
Messinger, Sheldon and John Berecochea

1990 Don't stay too long but do come back soon. Proceedings, Conference on Growth and Its Influence on Correctional Policy, Center for the Study of Law and Society, University of California at Berkeley.

Moore, Mark H., Susan R. Estrich, Daniel McGillis, and William Spelman

1984 Dangerous Offenders: The Elusive Target of Justice. Cambridge, Mass.: Harvard University Press.

National Institute of Justice

1990 Research in Action-Drug Use Forecasting. Washington, D.C.: U.S. Department of Justice.

Nelken, David

1982 Is there a crisis in law and legal ideology? Journal of Law and Society 9:177-189.

Pashukanis, Eugenii

1978 Law and Marxism: A General Theory, trans. Barbara Einhurn, London: Ink Links.

Petersilia, Joan

1987 Expanding Options for Criminal Sentencing. Santa Monica, Calif.: Rand.

President's Commission on Law Enforcement and the Administration of Justice 1967 The Challenge of Crime in a Free Society. Washington, D.C.,: Government Printing Office.

Rainwater, Lee

1966 Work and identity in the lower class. In Sam B. Warner (ed.), Planning for a Nation of Cities. Cambridge, Mass.: MIT Press.

Reichman, Nancy

1986 Managing crime risks: Toward an insurance-based model of social control. Research in Law, Deviance and Social Control 8:151-172.

Rothman, David

1971 The Discovery of the Asylum: Social Order and Disorder in the New Republic. Boston: Little, Brown.

1980 Conscience and Convenience: The Asylum and its Alternative in Progressive America. Boston: Little, Brown.

Sharlet, Robert

1978 Pashukanis and the withering away of law in the USSR. In Sheila Fitzpatrick (ed.), Cultural Revolution in Russia: 1928-1931. Bloomington: Indiana University Press.

Shaw, Clifford

1931 The Natural History of a Delinquent Career. 1968. Westport, Conn.: Greenwood Press.

Simon, Jonathan

1987 The emergence of a risk society: Insurance law and the state. Socialist Review 95:61-89.

1988 The ideological effect of actuarial practices. Law and Society Review 22:771-800.

1990 From discipline to management: Strategies of control in parole supervision, 1890-1990. Ph.D. dissertation, Jurisprudence and Social Policy Program, University of California at Berkeley. 
Steiner, Henry J.

1987 Moral Vision and Social Vision in the Court: A Study of Tort Accident

Law. Madison: University of Wisconsin Press.

Stone, Christopher

1975 Where the Law Ends. New York: Harper \& Row.

Sutherland, Edwin H.

1934 Principles of Criminology. Philadelphia: J.B. Lippincott.

Teubner, Gunther

1989 How the law thinks: Toward a constructivist epistemology of law. Law and Society Review 23:727-757.

Wilkins, Leslie T.

1973 Crime and criminal justice at the turn of the century. Annals of the American Academy of Political and Social Science 408:13-29.

Wilson, William Julius

1987 The Truly Disadvantaged: The Inner City, the Underclass, and Public Policy. Chicago: University of Chicago Press.

Zimring, Franklin and Gordon Hawkins

1991 The Scale of Imprisonment. Chicago: University of Chicago Press.

Malcolm M. Feeley is Professor of Law and Director of the Center for the Study of Law and Society at the University of California at Berkeley. He received his Ph.D. in political science in 1969, and he is the author of numerous books and articles. His book, The Process Is the Punishment (1979), received the American Bar Association's Silver Gavel Award and was cited as one of the best books in the past five years by the American Sociological Association's Criminal Justice Section.

Jonathan Simon is Assistant Professor in the Department of Political Science at the University of Michigan and currently Visiting Associate Professor of Law at the University of Miami. He received his Ph.D. and J.D. at the University of California at Berkeley, and he writes on the criminal process. His articles have appeared in Law \& Society Review and Law and Social Enquiry, and he is the author of a forthcoming book, to be published by the Univesity of Chicago Press, on the development of modern parole policies. 